\title{
Solid-State Anaerobic Digestion of Chicken Manure and Corn Straw with Different Loading Amounts
}

\author{
Hao Jiang ${ }^{1,2 *}$, Yi Shen², Chaoling $\mathrm{Ma}^{3}$, Jing Zhao², Yuchang Wang', \\ Yeqing $\mathrm{Li}^{2}$, Hongjun $\mathrm{Zhou}^{2}$ \\ ${ }^{1}$ Key Laboratory of Energy Resource Utilization, Ministry of Agriculture and Rural Affairs, \\ Chinese Academy of Agricultural Engineering, Beijing 100125, China \\ ${ }^{2}$ Beijing Key Laboratory of Biogas Upgrading Utilization, College of New Energy and Materials, \\ China University of Petroleum, Beijing 102249, China \\ ${ }^{3}$ Sinopec Nanjing Engineering \& Construction INC. (SNEI), Nanjing 211100, China
}

Received: 23 April 2020

Accepted: 18 June 2020

\begin{abstract}
Solid-state anaerobic digestion (SS-AD) is a promising process for organic waste treatment. The feeding amount and packing density is an important factor to affect the mass transfer and operating efficiency in SS-AD. This study investigated three different loading amounts of substrates, with the packing densities as $269 \mathrm{~g} / \mathrm{L}, 337 \mathrm{~g} / \mathrm{L}$ and $422 \mathrm{~g} / \mathrm{L}$, which were labelled as Batch 1, Batch 2 and Batch 3, respectively. The agricultural wastes, chicken manure and corn straw, were applied as feeding substrates. Leachate recirculation was employed to enhance the mass transfer. Several operating parameters were tested and the spatial distribution of microbial communities as well as the kinetics of biogas production were analyzed. Batch 2 and Batch 3 both showed good performance, although the higher packing density and leachate recirculation caused blockage in Batch 3. In contrast, Batch 1 with inadequate load worked inefficiently. In Batch 2, the spatial distribution of microorganisms was relatively uniform. Petrimonas and Ruminofilibacter were the dominant bacteria. The genus of Methanosarcina held $81 \%-94 \%$ of the archaea. The recirculation of leachate not only promoted the distribution and degradation of organic matters, but also made the soluble substrates and intermediates aggregate in the lower layer, affecting the distribution of the microorganisms.
\end{abstract}

Keywords: mass transfer, leachate recirculation, microbial community, packing density, biogas production

*e-mail: jianghao1028@foxmail.com 


\section{Introduction}

Anaerobic digestion (AD) of biodegradable material is a complex biological conversion driven by various microorganisms in the absence of oxygen. The three major types of microorganisms, hydrolytic-fermentative bacteria, acetogens and methanogens, work synergistically to complete the four steps of hydrolysis, acidogenesis, acetogenesis and methanogenesis. AD process can not only effectively degrade organic wastes to reduce pollutant discharge, but also produce biogas that could be used as an energy source. The development and application of AD technology will bring good environmental and economic benefits.

Based on the total solid (TS) content, AD technology can be divided into two types: liquid anaerobic digestion (L-AD) and solid-state anaerobic digestion (SS-AD). L-AD is usually operated with less than $15 \%$ TS, while SS-AD can handle higher TS substrates (20-40\% TS) $[1,2]$. Compared to L-AD, SS-AD has the advantages of less consumption of water and energy, higher organic loading rate, easier treatment of digested residues and simpler technique [1]. If the feedstocks are agricultural wastes such as livestock manure or straw, the fermented residues can be directly used as organic fertilizers. Previous studies have shown that SS-AD is suitable for co-digestion of livestock manure and straw [3, 4]. However, the SS-AD process required a large amount of inoculum for start-up and operation. The solid digestate from SS-AD is inefficient as inoculum due to its high content of undigested organic materials such as lignin with low microbial activity [5]. Another main drawback of SS-AD is the poor mass transfer, due to the less mixing mechanism and high TS content. This mass transfer limitation also brings the disadvantages of longer retention time, partial inhibitor accumulation, non-uniform waste degradation, etc. There is a number of techniques proposed to improve the performance of SS-AD. Mostly, they exert an effect on fermentation efficiency by enhancing biodegradability of the feedstock (e.g. substrates pretreatment, thermophilic fermentation), strengthening the mass transfer (e.g. mixing arrangement, leachate recirculation) and optimizing the process conditions (e.g. co-digestion, nutrient supplement) $[1,6,7]$.

SS-AD is a three-phase system consisting of the gas phase, the liquid film and the solid phase. The porous media, the fluid and the flow status determine fluid flow characteristics, and then affect the mass and heat transfer [8]. To enhance the mass transfer in SS-AD, leachate recirculation is commonly employed because it is easy to implement and can effectively redistribute water, substrates, nutrients and microorganisms [9]. As water is a high thermal entropy medium, the recirculation can also contribute to heat transfer [8]. Molecular diffusion and convection are two forms of mass transfer in SS-AD, depending on the properties of fluid flow and porous media. In the mobile water region, convection and dispersion both occur, while in the immobile water region, molecular diffusion is dominant [9].

Shewani et al. [10] showed that the macro-porosity volume decreased greatly while the micro-porosity volume increased after a compaction of batch SS-AD process. Besides the mechanical compaction due to more loading amount and higher loading density, the formation of biofilms and the degradation of organics accompanying $\mathrm{AD}$ process also contribute to the decrease of total pore space. André et al. [9] found that leachate recirculation could improve methane production rate at the early stage of SS-AD, but had no effect after 19 days. This may be caused by the pore destruction, which could lead the packing substrates more compact and impermeable. Li et al. [11] found that the continuous recirculation of leachate leads to a lower degradation degree of cellulose/hemicellulose and methane yield in SS-AD, so the recirculation speed should be optimized to minimize the disturbance and wash-out of the viable microbial consortium. For SS-AD process, it is necessary to select an appropriate loading amount and packing density, and the permeability decreasing in the middle and late stages should be taken into consideration. It is also possible to add supports in digestion or employ some substrates that can serve as supports.

The aim of this study was to investigate how the different loading amounts affected SS-AD process. Two kinds of common agricultural wastes, chicken manure and corn straw, were applied as feeding substrates. Small wood blocks were used as supports to improve the digestion permeability. Under three different loading amounts, the parameters of methane yield, $\mathrm{pH}$, VFA (volatile fatty acids), VFA/TIC (total inorganic carbon), COD (chemical oxygen demand), TAN (total ammonia nitrogen), FAN (free ammonia nitrogen) and lignocellulose components were tested. The spatial distribution of microbial communities was analyzed. Moreover, two models of modified Gompertz and Cone were employed to describe the kinetics of biogas production.

\section{Experimental}

\section{Experimental Setup}

The experiment of SS-AD was operated in a box-shaped batch reactor. A schematic diagram of the reactor is illustrated in Fig. 1. The volume of the fermentation chamber was $32 \mathrm{~L}$, while the volume of filter bed and leachate tank was $28 \mathrm{~L}$. The leachate was pumped up to the top of reactor and sprayed uniformly to the substrates. A biogas bag was connected to the fermentation chamber for biogas collection. The sidewalls were enclosed within a water jacket to maintain the reactor's inner temperature at $35 \pm 1^{\circ} \mathrm{C}$. 


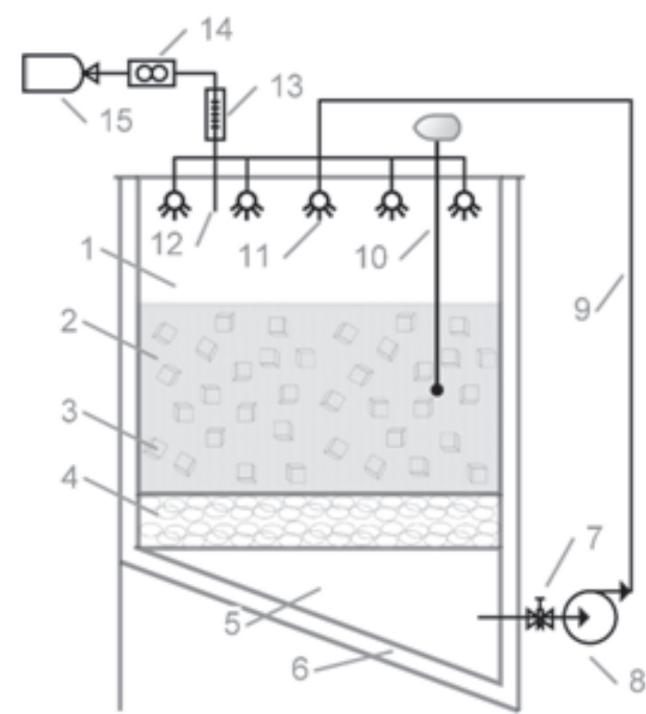

Fig. 1. Scheme of the solid-state anaerobic digester. (1) Fermentation chamber, (2) substrates, (3) wood block, (4) filter bed, (5) leachate tank, (6) water jacket, (7) sampling port, (8) pump, (9) leachate pipeline, (10) thermometer, (11) spray header, (12) biogas export, (13) condenser, (14) flowmeter, (15) gas bag.

\section{Feedstock and Reactor Operation}

Chicken manure and corn straw were used as substrates for anaerobic co-digestion. They were collected from Nankou Town, Changping District, Beijing, China. The pretreatment procedure for the corn straw consisted of cutting it into $2 \mathrm{~cm}$, soaking by $2 \% \mathrm{NaOH}$ at $90^{\circ} \mathrm{C}$ for $4 \mathrm{~h}$, washing by water and drying. Three batches with an increasing amount of substrate feeding were carried out one after another. The inoculum used in Batch 1 was the digestate from preculture experiments in the lab, while the inoculums of Batch 2 and Batch 3 were used the digestate from the previous batch. The TS and volatile solids (VS) of the feedstock are listed in Table 1. The substrate to inoculum ratio was 5.3 on the basis of VS. The whole TS content in each batch was $20 \%$, adjusted by adding water. A number of small wood blocks were mixed with the feedstock for support in the reactor. The size of the wood block is $2 \mathrm{~cm} \times 2 \mathrm{~cm} \times 1.5 \mathrm{~cm}$. The packing density was defined as the mass of the filling per unit volume. The filling included fresh substrates, inoculum and wood blocks, but the adding water was not counted.

The spray for recirculation started every two hours. In the early stage of fermentation, the recirculation of leachate in three batches were 10,20 and $30 \mathrm{~L} / \mathrm{d}$, respectively. It was about twice water content of each batch. When the methane concentration in biogas was over $60 \%$, the daily recirculation reduced by a quarter.

\section{Analytical Methods}

Biogas yield was monitored by a wet-type gas meter (TG05, Ritter, Germany), and converted to volume under standard conditions. Biogas composition was analyzed by gas chromatography with a thermal conductivity detector [12]. $\mathrm{pH}$ was determined by a $\mathrm{pH}$ meter (PH-10, Sartorius, Germany). TS and VS were determined according to standard methods [13].

For the analysis of VFA, COD and TAN, leachate was centrifuged at $10000 \mathrm{rpm}$ for $10 \mathrm{~min}$, and the supernatant was analyzed. VFA and VFA/TIC were determined by an automatic titrator (T70, MettlerToledo, Switzerland) according to a titration procedure $[14,15]$. COD was analyzed by the potassium dichromate oxidation method [13]. TAN was determined by a spectrophotometer (DR6000, HACH, USA) according to previous literature [15] and FAN was calculated using the formula proposed by Hansen et al [16]. The contents of hemicellulose, cellulose, and lignin were determined with a fiber analyzer (200I, ANKOM, USA) according to procedures supplied by ANKOM Technology [17].

\section{Analysis of Microbial Community by High-Throughput MiSeq Sequencing}

At the end of Batch 2 experiment, six samples of solid digestate were randomly collected from upper and lower parts in the fermentation chamber. The upper and lower parts were roughly divided by the middle of the packing height. The total DNA was extracted by the phenol-alcohol extraction method [18]. Primers 338F (5'-ACTCCTACGGGAGGCAGCA-3') and 806R

Table 1. Characteristics of the feedstock in the three batches.

\begin{tabular}{|c|c|c|c|c|c|c|}
\hline \multirow{2}{*}{ Batch } & \multicolumn{2}{|c|}{ Substrate } & \multirow{2}{*}{ Inoculum } & \multirow{2}{*}{$\begin{array}{l}\text { Substrate to } \\
\text { inoculum ratio } \\
\text { (VS basis) }\end{array}$} & \multirow{2}{*}{$\begin{array}{l}\text { Number of } \\
\text { supporting } \\
\text { blocks }\end{array}$} & \multirow{2}{*}{$\begin{array}{l}\text { Packing } \\
\text { density }\end{array}$} \\
\hline & Chicken manure & Corn straw & & & & \\
\hline 1 & $\begin{array}{c}\text { TS } 1200 \mathrm{~g} \\
\text { VS } 48.15 \pm 1.63 \%\end{array}$ & $\begin{array}{c}\text { TS } 120 \mathrm{~g} \\
\text { VS } 79.93 \pm 1.03 \%\end{array}$ & $\begin{array}{c}\text { Digestate from preculture } \\
\text { TS } 33.33 \pm 1.54 \% \mathrm{FM} \\
\text { VS } 32.59 \pm 1.38 \% \mathrm{TS}\end{array}$ & 5.3 & 140 & $269 \mathrm{~g} / \mathrm{L}$ \\
\hline 2 & $\begin{array}{c}\text { TS } 2400 \mathrm{~g} \\
\text { VS } 47.46 \pm 2.28 \%\end{array}$ & $\begin{array}{c}\text { TS } 240 \mathrm{~g} \\
\text { VS } 79.93 \pm 1.03 \%\end{array}$ & $\begin{array}{c}\text { Digestate from Batch } 1 \\
\text { TS } 37.36 \pm 1.11 \% \mathrm{FM} \\
\text { VS } 30.79 \pm 0.92 \% \mathrm{TS}\end{array}$ & 5.3 & 280 & $337 \mathrm{~g} / \mathrm{L}$ \\
\hline 3 & $\begin{array}{c}\text { TS } 3600 \mathrm{~g} \\
\text { VS } 45.43 \pm 1.27 \%\end{array}$ & $\begin{array}{c}\text { TS } 360 \mathrm{~g} \\
\text { VS } 79.93 \pm 1.03 \%\end{array}$ & $\begin{array}{c}\text { Digestate from Batch } 2 \\
\text { TS } 35.03 \pm 1.57 \% \text { FM } \\
\text { VS } 25.10 \pm 1.81 \% \mathrm{TS}\end{array}$ & 5.3 & 420 & $422 \mathrm{~g} / \mathrm{L}$ \\
\hline
\end{tabular}


(5'-GGACTACHVGGGTWTCTAAT-3') were used to amplify $16 \mathrm{~S}$ rRNA gene segments of bacteria. Primers Arch-519F (5'-CAGCCGCCGCGGTAA-3') and Arch915R (5'-GTGCTCCCCCGCCAATTCCT-3') were used to amplify archaeal 16S rRNA gene segments. Microbial analysis was performed on an Illumina MiSeq PE300 platform by Shanghai Majorbio Bio-pharm Biotechnology Co., Ltd. The analysis of microbial data was completed by R software [19].

\section{Kinetic Models}

Modified Gompertz (Equation 1) and Cone (Equation 2) models were employed to describe the kinetics of methane production [20].

$$
\begin{gathered}
M=P \times \exp \left\{-\exp \left[\frac{R_{m} \times e}{P}(\lambda-t)+1\right]\right\} \\
M=\frac{P}{1+(k \times t)^{-n}}
\end{gathered}
$$

...where $M$ represents the cumulative methane yield at a given time, $\mathrm{mL} / \mathrm{gVS} ; P$ is the maximum methane yield, $\mathrm{mL} / \mathrm{gVS} ; R_{m}$ is the maximum methane production rate, $\mathrm{mL} /(\mathrm{gVS} \cdot \mathrm{d}) ; e$ is equal to $2.71828 ; \lambda$ refers to the lag phase time, $\mathrm{d} ; t$ is the digestion time, $\mathrm{d} ; k$ is the rate constant, $1 / \mathrm{d} ; n$ is the shape factor, dimensionless.

Root Mean Square Prediction Error (rMSPE) and Akaike's Information Criterion (AIC) were calculated as Equation 3 and Equation 4 to evaluate goodness-offit of the models [21, 22].

$$
r M S P E=\sqrt{\sum_{i=1}^{n} \frac{\left(P V_{i}-M V_{i}\right)^{2}}{n}}
$$

...where $P V_{i}$ and $M V_{i}$ are predicted and measured methane volumes, respectively; $\mathrm{n}$ is the number of measurements.

$$
A I C=n \ln \left(\frac{R S S}{n}\right)+2(N+1)+\frac{2(N+1)(N+2)}{(n-N-2)}
$$

...where $\mathrm{n}$ is the number of data points; RSS is residual sum of squares; $\mathrm{N}$ is the number of model parameters.

\section{Results and Discussion}

\section{Methane Production Capability}

The fermentation periods of three batches were 27, 25 and 25 days, respectively. Fig. 2 shows the changes of cumulative methane yield, methane content and daily methane production over time. The cumulative methane yields in three batches were 145.1, 186.7 and $198.8 \mathrm{~mL} / \mathrm{gVS}$, respectively. That is, with the increase of feeding amount and packing density, the cumulative methane yields increased. This may be because that
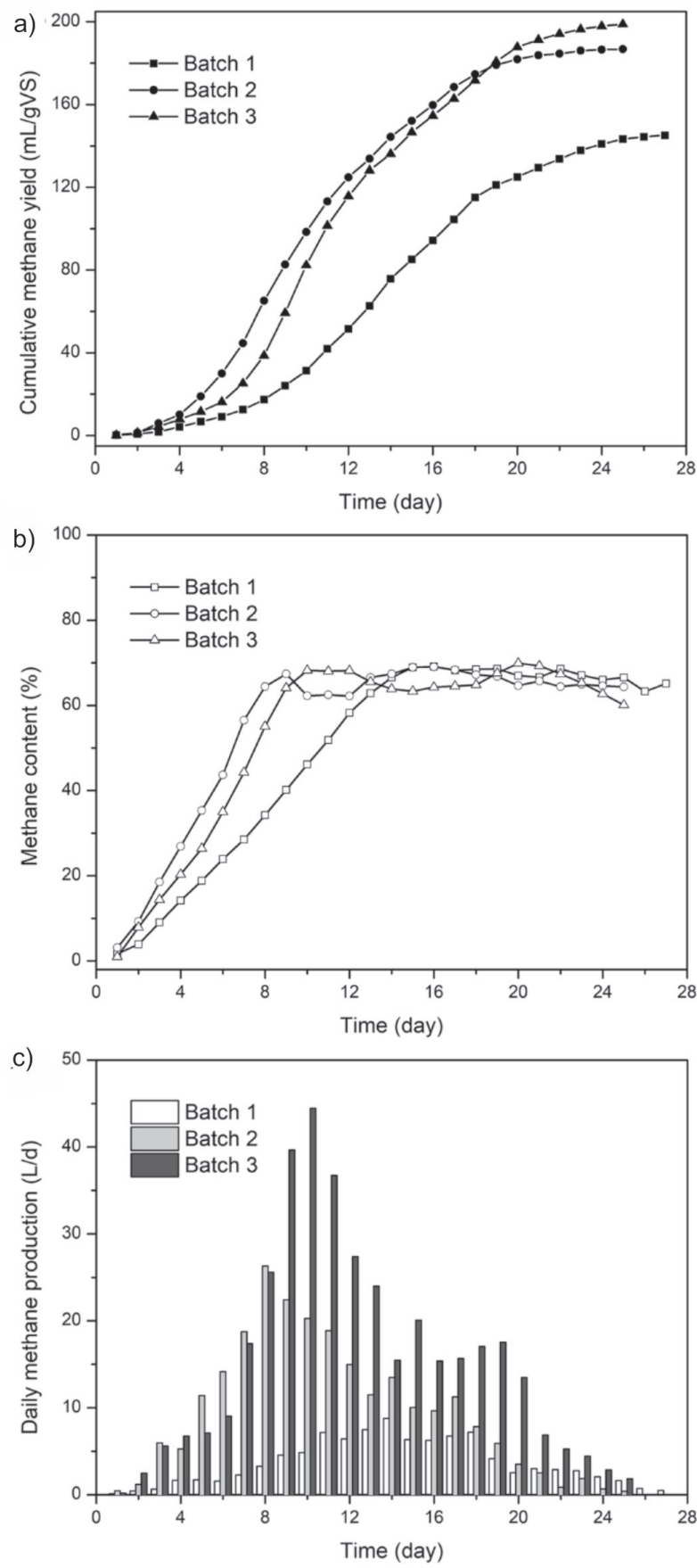

Fig. 2. Cumulative methane yield a), methane content b) and daily methane production c) of the three batches.

the more filling substrates added the packing height and recirculation volume of leachate, which helped leachate better distributed to promote heat and mass transfer.

In Batch 1, not only the final cumulative methane yield was lower, but also the increasing rates of cumulative methane yield and methane content were slower, comparing with Batch 2 and Batch 3. Due to the less feeding in Batch 1, the leachate may flow directly from the gaps to the reservoir without passing through the substrates, resulting in insufficient decomposition of organics and less effective production of methane. 
It can be seen from Fig. 2c) that the daily methane yield had two peaks in all the three batches. The first higher peak was probably due to the conversion of easily biodegradable components, while the second lower peak might be result of the degradation of more recalcitrant components [23]. The maximum daily methane production of the three batches occurred on the $14^{\text {th }}, 8^{\text {th }}$ and $10^{\text {th }}$ day, respectively, which was consistent with the time when methane content reached $60 \%$. In Batch 3, an obvious clogging emerged at the later fermentation, causing leachate accumulated at the upper part of the reactor. It is mainly because that Batch 3 had the highest packing density and the maximum volume of leachate recirculation. Meanwhile, the biofilm formation and organic decomposition could also reduce the porosity and permeability in the reactor [9]. Although the clogging did not influence methane production in this study, it may bring inefficiency and problems to the actual operation. Therefore, proper feeding amount, packing density and recirculation volume should be chosen to avoid blockage and maintain good performance.

\section{Process Monitoring}

To better compare the three batches, the parameters of $\mathrm{pH}, \mathrm{VFA} / \mathrm{TIC}, \mathrm{VFA}, \mathrm{COD}$, TAN and FAN were tested and are illustrated in Fig. 3. The whole process can be generally divided into two parts. In the first half of fermentation, VFA and COD increased in acidogenesis stage and decreased in methanogenesis; while in the second half, the different stages of $\mathrm{AD}$ maintained a balance and VFA as well as COD showed a slow declining trend.

The $\mathrm{pH}$ fluctuated in the range of 6.5 to 7.9 , which was appropriate for the microorganism growth in $\mathrm{AD}$ [24]. VFA/TIC, defining as a ratio between VFA and alkalinity, is an important indicator to evaluate the stability of AD process $[25,26]$. Similar to the changing trend of VFA and COD, the VFA/TIC ratio showed a peak in the first half of fermentation, and decreased gradually from around $0.5 \mathrm{gVFA} / \mathrm{gCaCO}_{3}$ to below $0.1 \mathrm{gVFA} / \mathrm{gCaCO}_{3}$ in the second half. The highest value of VFA/TIC appeared in Batch 3, which was $2.6 \mathrm{gVFA} / \mathrm{gCaCO}_{3}$. As reported, a VFA/TIC ratio of less than 0.5 was preferred to maintain a stable microbial community structure and avoid acidification in liquid $\mathrm{AD}[27,28]$. In $\mathrm{SS}-\mathrm{AD}$, this ratio could reach 1.2-1.4 without reactor failure [29, 30], while in this study, the ratio was even higher and the process performed well. It may be because that the high solid content in SS-AD relieved acid shocks and the recirculation of leachate promoted the distribution and degradation of VFA.

In all the batches, the fluctuation of ammonia nitrogen was slight, and the maximum concentrations of TAN and FAN were $2.31 \mathrm{~g} / \mathrm{L}$ and $0.13 \mathrm{~g} / \mathrm{L}$, respectively, which are much less than the concentrations at which ammonia is inhibitory [31, 32]. This was partly
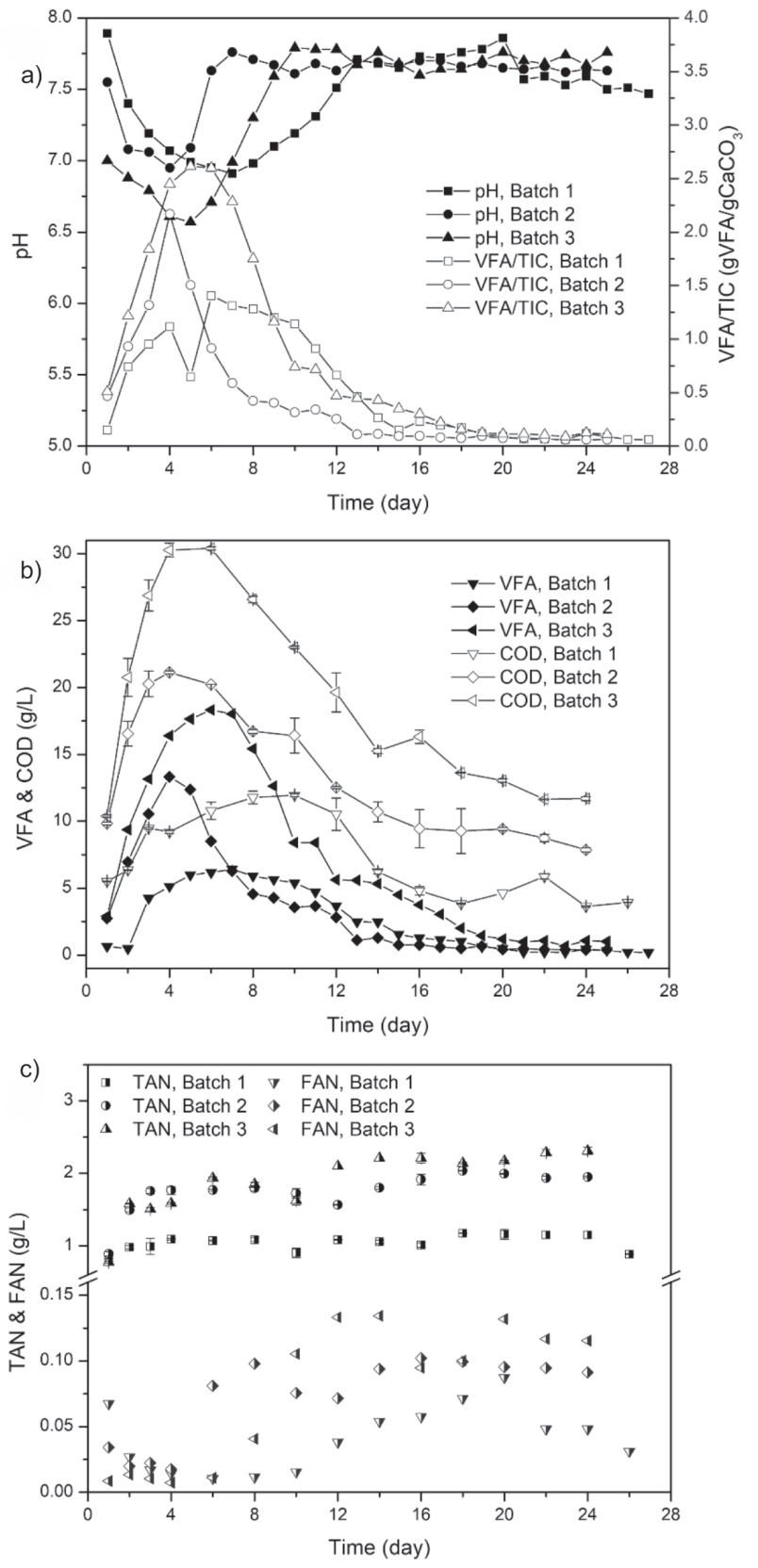

Fig. 3. $\mathrm{pH}$ and VFA/TIC a), VFA and COD b), TAN and FAN c) of the three batches.

benefited from the co-digestion with corn straw, which had higher carbon content than chicken manure.

Table 2 lists the lignocellulose components in substrates and solid digestates. In Batch 1 and Batch 2 , the samples from upper and lower solid digestates were collected respectively. In Batch 3, a significant blockage occurred at the later stage, so that the upper and lower solid could not be distinguished and only mixing samples were taken for analysis. In general, the content of cellulose and hemicellulose decreased while the relative content of lignin increased during the degradation process. The lower layer in the solid digestion presented a better degradation capacity of cellulose and hemicellulose comparing to the upper 
Table 2. Lignocellulose in chicken manure, corn straw and solid digestate.

\begin{tabular}{|c|c|c|c|}
\hline \multirow{2}{*}{ Samples } & \multicolumn{3}{|c|}{ Lignocellulose component (\%TS) } \\
\hline & Cellulose & Hemicellulose & Lignin \\
\hline \multicolumn{4}{|c|}{ Substrates } \\
\hline Chicken manure & $10.62 \pm 0.18$ & $22.23 \pm 1.58$ & $1.99 \pm 0.62$ \\
\hline Corn straw & $68.36 \pm 0.76$ & $9.35 \pm 0.23$ & $0.92 \pm 0.26$ \\
\hline \multicolumn{4}{|c|}{ Batch 1} \\
\hline Upper solid digestate & $5.25 \pm 2.11$ & $19.87 \pm 1.89$ & $3.72 \pm 1.48$ \\
\hline Lower solid digestate & $5.80 \pm 2.04$ & $4.78 \pm 1.32$ & $6.74 \pm 0.99$ \\
\hline \multicolumn{4}{|c|}{ Batch 2} \\
\hline Upper solid digestate & $9.66 \pm 1.21$ & $7.39 \pm 0.63$ & $11.25 \pm 2.11$ \\
\hline Lower solid digestate & $5.76 \pm 0.84$ & $5.38 \pm 0.45$ & $4.51 \pm 1.14$ \\
\hline \multicolumn{4}{|c|}{ Batch 3} \\
\hline Solid digestate & $3.99 \pm 1.62$ & $16.06 \pm 1.27$ & $2.17 \pm 1.03$ \\
\hline
\end{tabular}

layer. This may be because that the lower layer had better horizontal seepage, which improved the mass transfer and increased the removal rate of lignocellulose.

\section{Microbiological Analysis}

In Batch 2, the microbial communities at genus level of the upper and lower layers in the chamber were analyzed, as shown in Fig. 4. Generally, the community structure of bacteria and archaea in the six samples showed a good similarity, indicating the spatial distribution of microorganisms in the fermentation chamber was relatively uniform.

The dominant bacteria were Petrimonas and Ruminofilibacter, each taking around $15 \%$ of the total bacteria. Petrimonas are commonly seen in biogas reactors and other methanogenic environments [33]. They are strictly anaerobic, and can ferment carbohydrates as well as some organic acids to acetic acid [34]. Ruminofilibacter are responsible for the degradation of xylan [35]. Besides these two genera, vadinBC27, Ruminiclostridium, Aminobacterium also accounted for a prominent proportion. vadinBC27 were reported to play a key role in the degradation of recalcitrant organic contaminants [36]. Ruminiclostridium can ferment cellulose, xylan and cellobiose to VFA, $\mathrm{H}_{2}$ and $\mathrm{CO}_{2}$ [37]. Aminobacterium are syntrophic and capable of degrading amino acids, therefore, the abundance indicates high content of amino acids and protein in the fermenter [38, 39].

Another two genera, Proteiniphilum and Fastidiosipila, showed significantly different distribution patterns in upper and lower layers. Proteiniphilum, which are facultative anaerobe and can utilize proteins, yeast extract and carbohydrates as substrates [33], had more distribution in the lower layer of the chamber; while Fastidiosipila, which can contribute to the decomposition of cellulose [40], had more distribution in the upper layer. Besides, among the several prevailing genera mentioned above, Petrimonas, Ruminofilibacter and Aminobacterium were found more in the lower layer than in the upper layer. This could be due to the recirculation of leachate, which makes the soluble substrates and intermediates to aggregate in the lower layer, affecting the distribution of the microorganisms.

Compared to bacteria, the diversity of archaea was significantly lower, and the community structure of different samples presented a high similarity. The predominant genus, Methanosarcina, held 81\%-94\% of the archaea in the collected samples. The second most abundant archaea were Methanoculleus, which accounted for 5\%-17\%. And Methanomassiliicoccus roughly took the rest $1 \%$.

Methanosarcina can easily dominate in AD because they are tolerant to temperature variation as well as high levels of acetate, ammonium and salt. Also, they are able to use both the acetoclastic and the hydrogenotrophic pathway to produce methane [41, 42]. The other two genera, Methanoculleus produce methane via the hydrogenotrophic pathway [43], while Methanomassiliicoccus produce methane by reducing methanol with hydrogen as the electron donor [44].

\section{Kinetic Analysis}

The two models of modified Gompertz and Cone were applied to describe the kinetics of biogas production in the three batches. The kinetic parameters are estimated and listed in Table 3. Batch 3 showed the highest methane yield $(P)$ and methane production rate $\left(R_{\mathrm{m}}\right)$, which were $205.2 \mathrm{~mL} / \mathrm{gVS}$ and $17.09 \mathrm{~mL} /(\mathrm{gVS} \cdot \mathrm{d})$, respectively. The values of these two parameters in Batch 2 were slightly lower. In Batch 1, the values of $P$ and $R_{\mathrm{m}}$ were much lower, which were $157.4 \mathrm{~mL} / \mathrm{gVS}$ and $10.89 \mathrm{~mL} /(\mathrm{gVS} \cdot \mathrm{d})$, respectively. These results are 


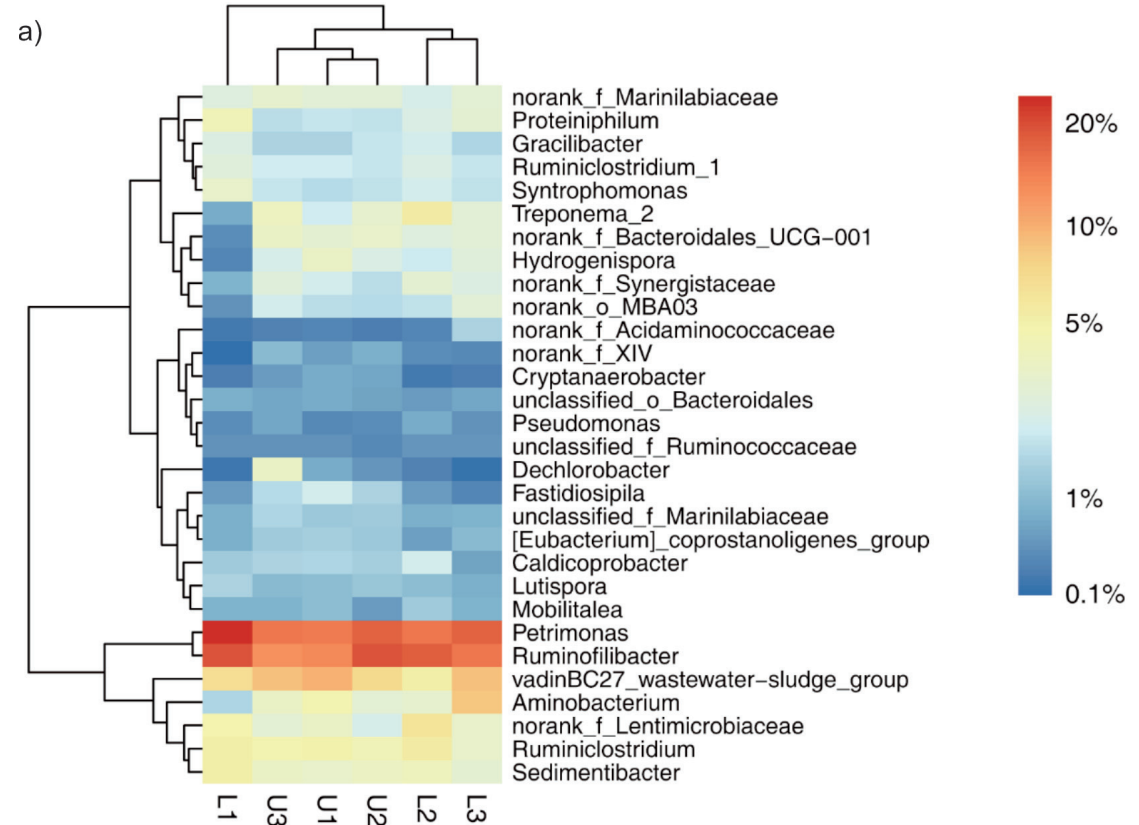

b)

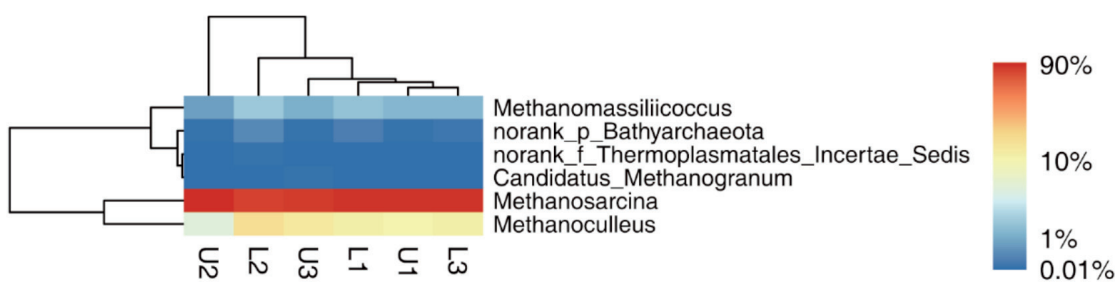

Fig. 4. Heatmap of bacterial a) and archaeal b) communities at genus level. The bacterial heatmap was based on the most abundant 30 genera. The colour scale on the right indicates the relative abundance of the OTUs. L1 to L3 represent three samples randomly collected from lower solid digestate, while U1 to U3 were from upper solid digestate.

consistent with the experimental results, suggesting that a certain amount of packing height and density for SS-AD is required to achieve good biogas production. The lag phase time $(\lambda)$ calculated from modified
Gompertz model were 7.03, 4.23 and $5.46 \mathrm{~d}$ in Batch 1, Batch 2 and Batch 3, respectively, indicating the loading volume of substrates in Batch 2 was suitable to obtain a quick start of the reactor. The rate constant $(k)$ in

Table 3. Model parameters of modified Gompertz and Cone model.

\begin{tabular}{|c|c|c|c|c|c|}
\hline Model & Parameter & Unit & Batch 1 & Batch 2 & Batch 3 \\
\hline \multirow{6}{*}{ Modified Gompertz } & $P$ & $\mathrm{~mL} / \mathrm{gVS}$ & $157.3862 \pm 1.7983$ & $191.8995 \pm 1.0777$ & $205.1884 \pm 2.4514$ \\
\hline & $R_{\mathrm{m}}$ & $\mathrm{mL} /(\mathrm{gVS} \cdot \mathrm{d})$ & $10.8850 \pm 0.2109$ & $16.7436 \pm 0.2600$ & $17.0927 \pm 0.4733$ \\
\hline & $\lambda$ & d & $7.0328 \pm 0.1241$ & $4.2336 \pm 0.0854$ & $5.4621 \pm 0.1550$ \\
\hline & $R^{2}$ & -- & 0.9987 & 0.9992 & 0.9977 \\
\hline & rMSPE & $\mathrm{mL} / \mathrm{gVS}$ & 1.87 & 1.82 & 3.39 \\
\hline & AIC & -- & 43.48 & 39.93 & 71.10 \\
\hline \multirow{6}{*}{ Cone } & $P$ & $\mathrm{~mL} / \mathrm{gVS}$ & $162.3733 \pm 2.1983$ & $201.0945 \pm 1.6784$ & $213.5783 \pm 3.4033$ \\
\hline & $k$ & $1 / \mathrm{d}$ & $0.0688 \pm 0.0000$ & $0.0977 \pm 0.0008$ & $0.0852 \pm 0.0012$ \\
\hline & $n$ & -- & $3.7073 \pm 0.0985$ & $3.1448 \pm 0.0682$ & $3.4973 \pm 0.1313$ \\
\hline & $R^{2}$ & -- & 0.9989 & 0.9992 & 0.9979 \\
\hline & rMSPE & $\mathrm{mL} / \mathrm{gVS}$ & 1.73 & 1.84 & 3.30 \\
\hline & AIC & -- & 39.41 & 40.41 & 69.65 \\
\hline
\end{tabular}


Cone model is another indicator reflecting the substrate biodegradability and digestion efficiency. The highest $k$ value 0.0977/d was found in Batch 2, indicating a maximum hydrolysis rate of the three batches.

The goodness-of-fit of the two models were evaluated by calculating and comparing the coefficient of determination $\left(R^{2}\right)$, rMSPE and AIC. The correlation coefficient ranged from 0.9977 to 0.9992 in modified Gompertz model and ranged from 0.9979 to 0.9992 in Cone model. The rMSPE ranged from 1.82 to $3.39 \mathrm{~mL} / \mathrm{gVS}$ in modified Gompertz model and ranged from 1.73 to $3.30 \mathrm{~mL} / \mathrm{gVS}$ in Cone model. The AIC ranged from 39.93 to 71.10 in modified Gompertz model and ranged from 39.41 to 69.65 in Cone model. These results indicate that both models have good accuracy and reliability for use in this study. But the goodnessof-fit in Batch 3 was not as well as that in Batch 1 and Batch 2, which may be due to the blockage affecting the performance.

\section{Conclusions}

For SS-AD, an appropriate packing height and density of feedstock can help to improve the mass transfer and the degradation efficiency. In this study, three different loading amounts of substrates were applied, and the packing densities were $269 \mathrm{~g} / \mathrm{L}, 337 \mathrm{~g} / \mathrm{L}$ and $422 \mathrm{~g} / \mathrm{L}$, respectively. Batch 2 and Batch 3 both showed good performance, while Batch 2 had shorter lag time and Batch 3 had higher efficiency of methane production. In Batch 2, the spatial distribution of microorganisms was relatively uniform, and due to the recirculation of leachate, the microorganisms degrading the soluble substance aggregated in the lower part. SS$\mathrm{AD}$ is a process with outstanding advantages, but the system is complicated, and we haven't had enough knowledge of the microscopic mechanisms and a deep understanding of the rules between operation and response. More research should focus on these aspects.

\section{Acknowledgements}

This work was supported by National Natural Science Foundation of China (21406263) and Science Foundation of China University of Petroleum, Beijing (2462015YQ1303).

\section{Conflict of Interest}

The authors declare no conflict of interest.

\section{References}

1. KARTHIKEYAN O.P., VISVANATHAN C. Bioenergy recovery from high-solid organic substrates by dry anaerobic bio-conversion processes: a review. Rev. Environ. Sci. Bio-Technol. 12, 257, 2013.

2. KOTHARI R., PANDEY A., KUMAR S., TYAGI V., TYAGI S. Different aspects of dry anaerobic digestion for bio-energy: An overview. Renew. Sust. Energ. Rev. 39, 174, 2014.

3. LI Y., LI Y., ZHANG D., LI G., LU J., LI S. Solid state anaerobic co-digestion of tomato residues with dairy manure and corn stover for biogas production. Bioresour. Technol. 217, 50, 2016.

4. LI Y., ZHANG R., CHEN C., LIU G., HE Y., LIU X. Biogas production from co-digestion of corn stover and chicken manure under anaerobic wet, hemi-solid, and solid state conditions. Bioresource. Technol. 149, 406, 2013.

5. MENG L., MARUO K., XIE L., RIYA S., TERADA A., HOSOMI M. Comparisonof leachate percolation and immersion using different inoculation strategies in thermophilic solid-state anaerobic digestion of pig urine and rice straw. Bioresource. Technol. 277, 216, 2019.

6. YANG L., XU F., GE X., LI Y. Challenges and strategies for solid-state anaerobic digestion of lignocellulosic biomass. Renew. Sust. Energ. Rev. 44, 824, 2015.

7. LU Y., ZHANG Q., WANG X.Y., ZHONG H., ZHU J.Y. Effects of initial microbial community structure on the performance of solid-state anaerobic digestion of corn stover. Journal of cleaner production. 260, 2020.

8. CHEN H. Modern solid state fermentation; Springer: Netherlands, 2013.

9. ANDRÉ L., DURANTE M., PAUSS A., LESPINARD O., RIBEIRO T., LAMY E. Quantifying physical structure changes and non-uniform water flow in cattle manure during dry anaerobic digestion process at lab scale: implication for biogas production. Bioresource. Technol. 192, 660, 2015

10. SHEWANI A., HORGUE P., POMMIER S., DEBENEST G., LEFEBVRE X., GANDON E., PAUL, E. Assessment of percolation through a solid leach bed in dry batch anaerobic digestion processes. Bioresource. Technol. 178, 209, 2015.

11. LI C., TAO Y., FANG J., LI Q., LU W.J. Impact of continuous leachate recirculation during solid state anaerobic digestion of Miscanthus. Renew Energ. 154, 38, 2020.

12. JIANG H., NIE H., DING J., STINNER W., SUN K., ZHOU H. The startup performance and microbial distribution of an anaerobic baffled reactor (ABR) treating medium-strength synthetic industrial wastewater. J. Environ. Sci. Health Part A. 1, 2017.

13. APHA, AWWA, WEF Standard methods for the examination of water and wastewater; 21 ed., American Public Health Association (APHA), American Water Work Association (AWWA) and Water Environment Federation (WEF): Washington, DC, 2005.

14. BUCHAUER K. A comparison of two simple titration procedures to determine volatile fatty acids in influents to waste-water and sludge treatment processes. Water. SA. 24, 49, 1998.

15. NIE H., JACOBI H.F., STRACH K., XU C., ZHOU H., LIEBETRAU J. Mono-fermentation of chicken manure: ammonia inhibition and recirculation of the digestate. Bioresource. Technol. 178, 238, 2015.

16. HANSEN K.H., ANGELIDAKI I., AHRING B.K. Anaerobic digestion of swine manure: inhibition by ammonia. Water. Res. 32, 5, 1998.

17. JIANG H., ZENG Y., NIE H., LI Y., DING J., ZHOU $\mathrm{H}$. $\mathrm{NaOH}$ pretreatment of wheat straw at a mesophilic 
temperature: effect on hydrolysis and loss of organic carbon. Pol. J. Environ. Stud. 25, 1541, 2016.

18. FREDERICK M.A., ROGER B., ROBERT E., DAVID D., SEIDMAN J., JOHN A., KEVIN S. Short Protocols in Molecular Biology; $3^{\text {rd }}$ ed., Wiley: New York, 1995.

19. R: A language and environment for statistical computing. R Foundation for Statistical Computing, Vienna: Austria. https://www.R-project.org.

20. LI Y., ZHANG R., HE Y., LIU X., CHEN C., LIU G. Thermophilic solid-state anaerobic digestion of alkalinepretreated corn stover. Energ. Fuel. 28, 3759, 2014.

21. WANG M., TANG S., TAN Z. Modeling in vitro gas production kinetics: Derivation of Logistic-Exponential (LE) equations and comparison of models. Anim. Feed. Sci. Tech. 165, 137, 2011,

22. EL-MASHAD H.M. Kinetics of methane production from the codigestion of switchgrass and Spirulina platensis algae. Bioresource. Technol. 132, 305, 2013.

23. VASCO-CORREA J., LI Y. Solid-state anaerobic digestion of fungal pretreated Miscanthus sinensis harvested in two different seasons. Bioresource. Technol. 185, 211, 2015.

24. FNR. Guide to Biogas-From Production to Use; $5^{\text {th }}$ ed., Fachagentur Nachwachsende Rohstoffe e.V. (FNR): Gülzow, 2010.

25. WAN C., ZHOU Q., FU G., LI Y. Semi-continuous anaerobic co-digestion of thickened waste activated sludge and fat, oil and grease. Waste. Manage. 31, 1752, 2011.

26. ZHANG W., WEI Q., WU S., QI D., LI W., ZUO Z., DONG R. Batch anaerobic co-digestion of pig manure with dewatered sewage sludge under mesophilic conditions. Appl. Energ. 128, 175, 2014.

27. VOB E., WEICHGREBE D., RESENWINKEL K. FOS/ TAC-Deduction, Methods, Application and Significance. Internationale Wissenschaftskonferenz Biogas Science 2009.

28. RIAU V., DE LA RUBIA M. Á., PÉREZ M. Temperaturephased anaerobic digestion (TPAD) to obtain class A biosolids: A semi-continuous study. Bioresource.Technol. 101, 2706, 2010

29. WALTER A., PROBST M., HINTERBERGER S., MÜLLER H., INSAM H. Biotic and abiotic dynamics of a high solid-state anaerobic digestion box-type container system. Waste. Manage. 49, 26, 2016.

30. BROWN D., LI Y. Solid state anaerobic co-digestion of yard waste and food waste for biogas production. Bioresource. Technol. 127, 275, 2013.

31. DUAN N., DONG B., WU B., DAI X. High-solid anaerobic digestion of sewage sludge under mesophilic conditions: feasibility study. Bioresource. Technol. 104, 150, 2012.

32. YENIGÜN O., DEMIREL B. Ammonia inhibition in anaerobic digestion: a review. Process Biochem. 48, 901, 2013.

33. HAHNKE S., LANGER T., KOECK D.E., KLOCKE M. Description of Proteiniphilum saccharofermentans sp. nov., Petrimonas mucosa sp. nov. and Fermentimonas caenicola gen. nov., sp. nov., isolated from mesophilic laboratory-scale biogas reactors, and emended description of the genus Proteiniphilum. Int. J. Syst. Evol. Micr. 66, 1466, 2016.

34. GRABOWSKI A., TINDALL B.J., BARDIN V., BLANCHET D., JEANTHON C. Petrimonas sulfuriphila gen. nov., sp. nov., a mesophilic fermentative bacterium isolated from a biodegraded oil reservoir. Int. J. Syst. Evol. Micr. 55, 1113, 2005.

35. WEIß S., ZANKEL A., LEBUHN M., PETRAK S., SOMITSCH W., GUEBITZ G. Investigation of mircroorganisms colonising activated zeolites during anaerobic biogas production from grass silage. Bioresource. Technol. 102, 4353, 2011.

36. XIE Z., WANG Z., WANG Q., ZHU C., WU Z. An anaerobic dynamic membrane bioreactor (AnDMBR) for landfill leachate treatment: performance and microbial community identification. Bioresource. Technol. 161, 29, 2014.

37. YUTIN N., GALPERIN M.Y. A genomic update on clostridial phylogeny: Gram-negative spore formers and other misplaced clostridia. Environ. Microbiol. 15, 2631, 2013.

38. CHERTKOV O., SIKORSKI J., BRAMBILLA E., LAPIDUS A., COPELAND A., DEL RIO T.G., NOLAN M., LUCAS S., TICE H., CHENG J.-F. Complete genome sequence of Aminobacterium colombiense type strain $\left(\mathrm{ALA}^{\mathrm{T}}{ }^{\mathrm{T}}\right)$. Stand. Genomic. Sci. 2, 280, 2010.

39. LI A., CHU Y.N., WANG X., REN L., YU J., LIU X., YAN J., ZHANG L., WU S., LI S. A pyrosequencingbased metagenomic study of methane-producing microbial community in solid-state biogas reactor. Biotechnol. Biofuels. 6, 3, 2013.

40. ZHAO X., LIU J., LIU J., YANG F., ZHU W., YUAN X., HU Y., CUI Z., WANG X. Effect of ensiling and silage additives on biogas production and microbial community dynamics during anaerobic digestion of switchgrass. Bioresource. Technol. 241, 349, 2017.

41. DE VRIEZE J., HENNEBEL T., BOON N., VERSTRAETE W. Methanosarcina: the rediscovered methanogen for heavy duty biomethanation. Bioresource. Technol. 112, 1, 2012.

42. YU D., KUROLA J., LÄHDE K., KYMÄLÄINEN M., SINKKONEN A., ROMANTSCHUK M. Biogas production and methanogenic archaeal community in mesophilic and thermophilic anaerobic co-digestion processes. J. Environ. Manage. 143, 54, 2014.

43. NAZARIES L., MURRELL J.C., MILLARD P., BAGGS L., SINGH B.K. Methane, microbes and models: fundamental understanding of the soil methane cycle for future predictions. Environ. Microbiol. 15, 2395, 2013.

44. DRIDI B., FARDEAU M.-L., OLLIVIER B., RAOULT D., DRANCOURT M. Methanomassiliicoccus luminyensis gen. nov., sp. nov., a methanogenic archaeon isolated from human faeces. Int. J. Syst. Evol. Micr. 62, 1902, 2012. 